\title{
Effects of Almaty city ecological factors on students blood indices
}

\author{
Tilek Baidaulet ${ }^{1,3 *}$, Alibek Ydyrys ${ }^{2}$, Moldir Imanaliyeva ${ }^{3}$, Zifa Askarova $^{3}$, Gulziya \\ Srailova $^{3}$, Maira Murzakhmetova ${ }^{3}$ and Sultan Tuleukhanov ${ }^{3}$ \\ ${ }^{1}$ Asfendiyarov Kazakh National Medical University, 94 Tole bi Str. 050000 Almaty, Kazakhstan \\ ${ }^{2}$ Al-Farabi Kazakh National University, Biomedical research centre. 71 al-Farabi Ave. 050040 \\ Almaty, Kazakhstan \\ ${ }^{3}$ Al-Farabi Kazakh National University, 71 al-Farabi Ave. 050040 Almaty, Kazakhstan
}

\begin{abstract}
This research gives an insight into the main features of the cardiovascular system's statistical and dynamic, as well as young local and foreign citizens in Almaty city adaptation indices. 1500 analysis of blood indices was carried out before and after the physical workload. Hematological research were carried out based on N. M. Mykolayiv method and included the erythrocytes and leukocytes count in peripheral blood vessel and absolute number of lymphocytes . Foreign students' absolute amount of leukocytes and erythrocytes in the peripheral blood vessels and the phagocytic activity of neutrophil were different from local students' indices.
\end{abstract}

\section{Introduction}

Environment is the sum of all conditions and influences that affect the development and life of all organisms on earth. [1]. The environment affects our health in a variety of ways. The interactions between human health and the environment has been extensively studied and environmental risks have been proven to significantly impact human health, either directly by exposing people to harmful agents, or indirectly, by disrupting life-sustaining ecosystems [2].

The ultimate purpose for the cardiovascular system is to facilitate exchange of gases, fluid, electrolytes, large molecules and heat between cells and the outside environment [3]. Contact with unsafe drinking or bathing water can impose serious risks (both acute and delayed) to human health [4;5].

All the cardiovascular changes occurring during physical activity ensure that active muscles are supplied with increased blood flow and oxygen while maintaining normal, or even elevated, arterial pressures [3]. Sulfur dioxide irritates respiratory tissues. Chronic exposure causes a condition similar to bronchitis [6]. It is shown that the adverse ecological factors of environment have harmful effect to the human blood indices. The characters and extent of the effect was depending on the ecological condition [7].

\footnotetext{
* Corresponding author: aduinger@gmail.com
} 


\section{Materials and Methods}

50 young girl students were examined and information is listed in the following table1. They were examined before and after the physical workload, time: 14:00 - 17:00, December to January. And they were estimated to make a prediction to their cardiovascular system status.

Table 1. information of objects

\begin{tabular}{|l|l|l|l|l|l|}
\hline Group & $\begin{array}{l}\text { Number of } \\
\text { students }\end{array}$ & Age, year & Weight, kg & Height, cm & Origin \\
\hline First group & 20 & $18-22$ & $48-65$ & $150-170$ & Almaty city \\
\hline $\begin{array}{l}\text { Second } \\
\text { group }\end{array}$ & 15 & $18-21$ & $50-66$ & $158-169$ & $\begin{array}{l}\text { southern } \\
\text { Kazakhstan }\end{array}$ \\
\hline Third group & 15 & $18-22$ & $52-70$ & $155-170$ & $\begin{array}{l}\text { Western } \\
\text { Kazakhstan }\end{array}$ \\
\hline overall & 50 & $18-22$ & $48-70$ & $150-170$ & - \\
\hline
\end{tabular}

They all were university students in Almaty, and were kept normal mode of labor and rest. The study was carried out at Keremet medical center in Almaty. Indoor temperature was $22-25 \mathrm{C}^{\circ}$. outdoor was $-7,-10 \mathrm{C}^{\circ}$.

The blood indices analysis was carried out before and after the physical workload. Therefore, we did 1500 times research among the students. The hematological research included the erythrocytes count in peripheral blood vessel, leukocytes count in peripheral blood vessel and the absolute number of lymphocytes and they were carried on based on $\mathrm{N}$. M. Mykolayiv method.

The research was conducted over three years.

\section{Results and Discusson}

Table 2 shows the results of measuring the number of white blood cells in different groups before and after exercise.

Table 2. Leukocytes counts in the peripheral blood vessels of the students before and after the physical workload

\begin{tabular}{|c|l|r|r|r|l|l|}
\hline \multirow{2}{*}{} & \multicolumn{2}{|c|}{$2017-2018$} & \multicolumn{2}{c|}{$2018-2019$} & \multicolumn{2}{c|}{$2019-2020$} \\
\cline { 2 - 7 } & before & after & before & after & before & after \\
\hline $\begin{array}{c}\text { First group } \\
\text { (control group) }\end{array}$ & 5627.6 & 6200.4 & 5630.7 & 6140.3 & 5618.5 & 6112.4 \\
\hline Second group & 5523.1 & 6950.7 & 5862.9 & 7163.5 & 5702.5 & 6702.4 \\
\hline Third group & 5952.8 & 6968.3 & 5752.9 & 6600.7 & 5809.7 & 6849.4 \\
\hline
\end{tabular}

The results of these studies showed that the volume of blood fluid students of the second group was higher than in the local group of students, the number of leukocytes in 1 
MKL of blood in the second group was also lower than in the local group of students, the average level of the absolute number of leukocytes in the third group were significantly higher than other groups in the first year. It can be concluded that the climatic and geographical conditions of students in the second and third groups were more severe than those of students in the control area. The reason for this was that the students came from a region that had a lower air temperature, the body of students in this group was adapted to harsh climatic and geographical conditions than in the control groups. In subsequent years, the indicators of students in the second and third groups change, while in the first group they remain approximately at the same level. It can be concluded that the body of students has already adapted to severe and serious climatic and geographical conditions, and not to local climatic and geographical conditions.

Table 2 also shows that after exercise, the number of white blood cells in the peripheral blood vessels increased incredibly. However, this change is noticeably greater in the second and third groups. than in the control group.

The absolute number of lymphocytes in peripheral blood vessels was also analyzed in students of Almaty city, both of local origin, and from western and southern Kazakhstan, the results are shown in table 3

Table 3. Lymphocyte counts in the peripheral blood vessels of the students before and after the physical workload

\begin{tabular}{|l|c|c|c|c|c|c|}
\hline \multirow{2}{*}{} & \multicolumn{2}{|c|}{$2017-2018$} & \multicolumn{2}{|c|}{$2018-2019$} & \multicolumn{2}{|c|}{$2019-2020$} \\
\cline { 2 - 7 } & after & before & after & after & before & after \\
\hline $\begin{array}{l}\text { First group } \\
\text { (control } \\
\text { group) }\end{array}$ & 23.14 & 25.22 & 23.9 & 25.02 & 24.04 & 25.07 \\
\hline Second group & 25.62 & 28.9 & 23.61 & 27.01 & 25.79 & 27.14 \\
\hline Third group & 25.17 & 29.19 & 25.45 & 28.76 & 27 & 28.36 \\
\hline
\end{tabular}

According to the research results, there were much more obvious changes in the immune system of students to adapt to the new climatic and geographical conditions of Almaty cities from foreign climatic and geographical conditions. In contrast to local students living in Almaty, students from the southern and Western parts of the Republic of Kazakhstan all indicators, such as the absolute number of white blood cells in peripheral blood vessels, the absolute number of lymphocytes in peripheral blood vessels and phagocytic activity of neutrophils, differed from the indicators of local students, and this gives us an opportunity to judge the large dynamics and activity of functional blood indicators when adapting to new extreme conditions.

\section{Conclusions}

In conclusion, it should be noted that the indicators of the cardiovascular system of students living in the southern and Western parts of the Republic of Kazakhstan were more sensitive than those of local students living in the city of Almaty, so their bodies faced the need to adapt. The results show that the physiological indicators of the functional state of students 
who arrived from other parts of the Republic of Kazakhstan, significantly change relative to the initial year of study, while the local students did not change. Students ' blood counts demonstrate the adaptation process. It should also be noted that physical activity significantly affects students from other parts of the Republic of Kazakhstan, both in the initial year and in subsequent years.

\section{References}

1. World Health Organization. Preventing disease through healthy environment: Towards an estimate of the environmental burden of disease. Available online: http://www.who.int/ quantifying_ehimpacts/

publications/preventingdisease/en/index.html. (2017)

2. K.D. Anil, Environment and ecology, 23-36 (New Age International (P) Ltd., New Delhi, 2009)

3. R.E. Klabunde, Cardiovascular Physiology Concepts, 56-62. (Lippincott Williams \&Wilkins. USA, 2005)

4. Human physiology, 32-45. (Wikibooks contributors, 2006) Available online:

http://en.wikibooks.org/wiki/Human_Physiology

5. E. Bharucha, Textbook for environmental studies for undergraduate courses, 35-48 (University Grants commission, New Delhi, 2004)

6. T. Baidaulet, S.T. Tuleuhanov, N.T. Ablaikhanova, A. Ydyrys, A. Baishanbo, Int. J. of Biology and Chemistry, 10(1), 42-49 (2017) 